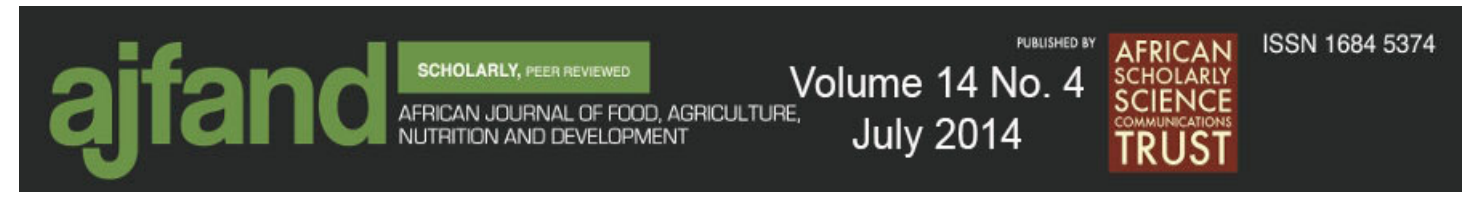

\title{
EFFECT OF STAGE OF LACTATION ON THE PHYSICAL AND CHEMICAL COMPOSITION OF DRÂA GOAT MILK
}

\section{Noutfia $\mathrm{Y}^{1^{*}}$, Zantar $\mathrm{S}^{2}$, Ibnelbachyr $\mathrm{M}^{3}$, Abdelouahab $\mathrm{S}^{4}$ and I Ounas ${ }^{4}$}

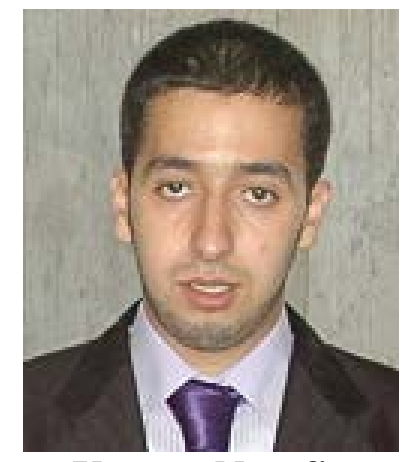

Younes Noutfia

${ }^{*}$ Corresponding author email: noutfiaa@yahoo.fr

${ }^{1}$ Resarch Unit on Saharan Agronomy, Regional Center of Agronomic Research of ERRACHIDIA, National Institute of Agronomic Research, Morocco

${ }^{2}$ Research Unit on Nuclear Techniques, Environment and Quality, Regional Center of Agronomic Research of TANGIER, National Institute of Agronomic Research, Morocco

${ }^{3}$ Department of Animal Production, Regional Center of Agronomic research of ERRACHIDIA, National Institute of Agronomic Research, Morocco

${ }^{4}$ Department of Biology, Faculty of Technical Sciences of ERRACHIDIA, University of Moulay Ismail, MEKNES, Morocco 


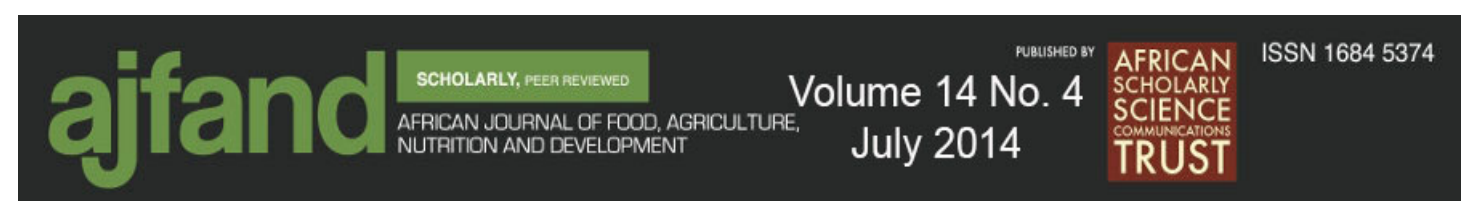

\begin{abstract}
Raw milk characterization constitutes a preliminary and an important step to take account in order to obtain an optimal technological valorization. Among other factors, breed, feed and stage of lactation are the most important factors that influenced cheese making and other dairy products valorization. Thus, this study proposes to analyze the physicochemical composition of Drâa goat milk and to study raw milk fluctuations throughout a complete lactation period. The study was carried out in the Experimental Station of Errachidia (Southern Morocco). In this context, sixteen goats were selected and sampled every week during a period of 160 days (average lactation length). A total of 128 samples of raw goat milk were analyzed according to international standards. Analyses were focused to determination of $\mathrm{pH}$, acidity, density, Dry Matter (DM), Solids Non Fat (SNF), ash, fat and Total Nitrogenous Matter (TNM). Average values were about $17.8^{\circ} \mathrm{D}$ for acidity, $13.3 \%$ for Dry Matter, $0.73 \%$ for ash, $4.16 \%$ for fat and $3.60 \%$ for Total Nitrogenous Matter. In general, theses values are largely situated in the upper level of the range suggested by several Moroccan and foreign researchers for other goat species. On the other hand, the evolution of physical and chemical parameters throughout lactation stages showed that dry matter, fat content and total nitrogenous matter increased significantly throughout the lactation period; the opposite was found for density $(\mathrm{p}<0.001)$. No significant $(\mathrm{p}>0.05)$ changes were shown for milk acidity and the average found was around $17^{\circ} \mathrm{D}$. Content of milk ash increased significantly during the late lactation stage compared to the earliest and the opposite was observed for $\mathrm{pH}$.The results of the present investigation show that Drâa goat milk is rich with desirable components like fat and protein for dairy product manufacturers, and that the late lactation stage seems to be the best period to ensure an optimum technological valorization.
\end{abstract}

Key words: Goat, Morocco, milk, physicochemical, lactation 


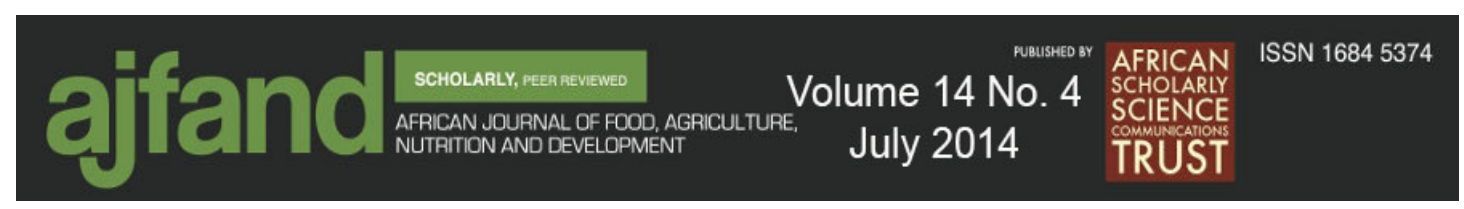

\section{INTRODUCTION}

In Morocco, cattle and goats dairy systems have improved in the recent years. Production has tripled in the last 30 years and, among other economic and social positive factors, Morocco's dairy goat production has increased to $80 \%$ of selfsufficiency and, as a result of milk sales, 300000 breeders get a stable and regular income of about $50 \mathrm{MDH}$ (Moroccan currency) /day [1]. However, this system has now reached its limits in relation to an issue of access to a larger number of consumers because of a very low specific consumption of about 100 grams per day corresponding to half of the nutritional requirements recommended by international organizations and because of a very high price compared to the Benchmark [1].

At the oasis area of southern Morocco and following the workshops held between research and development organizations in 2004, the sector of goat farming in general and race Drâa in particular has been selected among the priority for research in this area. With a flock size of approximately 12500 dairy goats and an average milk production capacity of 1.5 liters per day [2], the Drâa goat is bred in small flocks in the oases of the Drâa river valley that extends $200 \mathrm{~km}$ in southern Morocco between Ouarzazate and Zagora [3]. Furthermore, the valorization of goat milk cheese seems to ensure better profitability of milk production and thus, is an important force behind the development of the goat population in this area which has a very fragile economy. However, research on the physicochemical composition of goat milk is very limited or even absent.

In order to bridge this gap, this study proposes to characterize the physicochemical composition of Drâa goat milk and to determine the fluctuations that know this composition throughout lactation in order to determine the appropriate period ensuring a better valorization of this goat's raw milk.

\section{MATERIALS AND METHODS}

\section{Sampling}

Milk samples (about $250 \mathrm{ml}$ per sample) were obtained periodically from a milk mixture of evening and morning milking from a herd of 16 Drâa goats raised at the Experimental Station of Errachidia (ESE). Samples of raw milk were stored at $+4{ }^{\circ} \mathrm{C}$ between the two milkings and during laboratory analysis. The transfer of samples between the goat unit and the laboratory did not take 5 minutes. The total number of samples analyzed throughout this study was 128 samples during 160 days. To avoid the analysis of milk during the colostral period, sampling did not begin until the 3rd week of kidding

\section{Laboratory Analysis}

The characterization of the main physicochemical parameters of the Drâa goat milk was focused on the determination of $\mathrm{pH}$, acidity, density, Dry Matter (DM), Solids Non fat (SNF), ash, fat and Total Nitrogenous Matter (TNM) in accordance with 


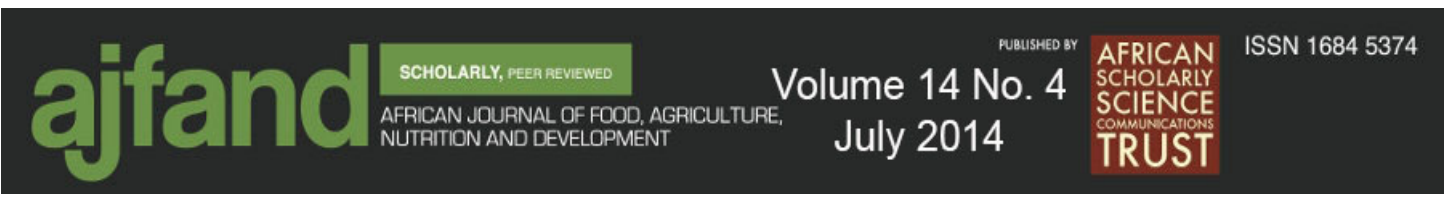

international standards [4]. Analyses were performed with two replicates for each sample.

\section{Statistical analysis}

Initially, a determination of the mean, Standard Deviation (SD), minimum and maximum of each parameter analyzed was made, and then the profile of weekly variation of the levels of DM, fat and TNM was elaborated. The effect of lactation stage on the physicochemical composition of milk was determined by analysis of variance with one criterion of classification (ANOVA1) to know the stage of lactation. The data was analyzed using Excel-2007.

\section{RESULTS}

Characterization of the physicochemical composition of Drâa goat milk The average values of the physical ( $\mathrm{pH}$, acidity and density) and the chemical components of milk (DM, ash, fat and TNM) are shown in Table 1.

\section{The evolution of fat and TNM during lactation}

Figure 1 shows the evolution of the TNM and fat for 160 days from the 3rd week of kidding.

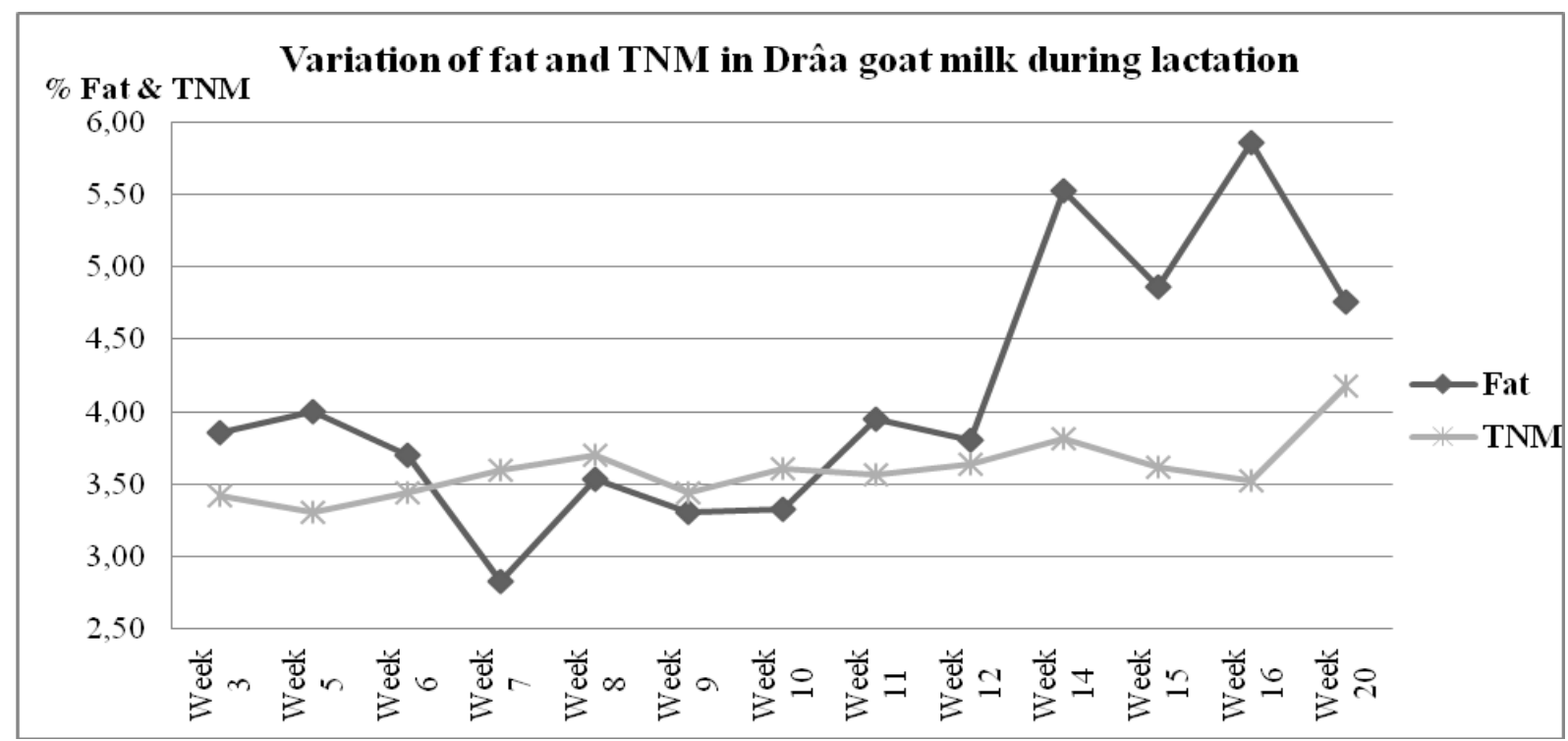

Figure 1: Variation of fat and TNM in Drâa goat milk during lactation

The amount of milk required to conduct laboratory analyzes was insufficient for the weeks 13, 17, 18 and 19; so those weeks were excluded from the figure.

Fat content began to increase from the 12th week after kidding until the end of lactation. However, TNM contents remained stable during lactation until the 16th week. After this period, a significant increase was observed. 


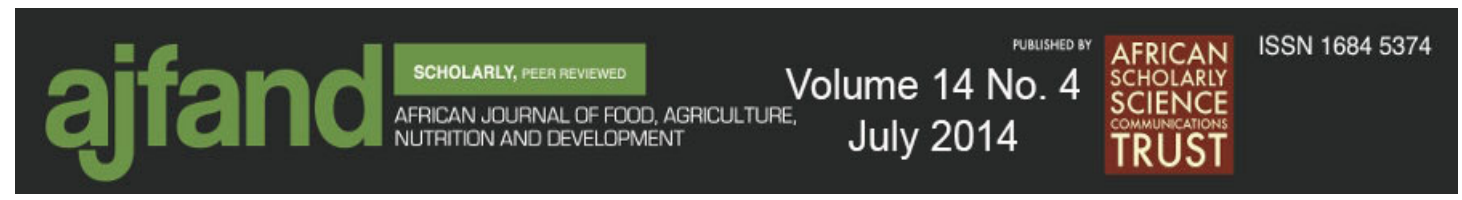

Generally, pace of change of fat is more pronounced compared to the total nitrogenous matter.

\section{Study of the evolution of DM \& Solids Non Fat (SNF) during lactation}

Figure 2 shows the variation in DM and SNF, for 160 days from the 3rd week of kidding.

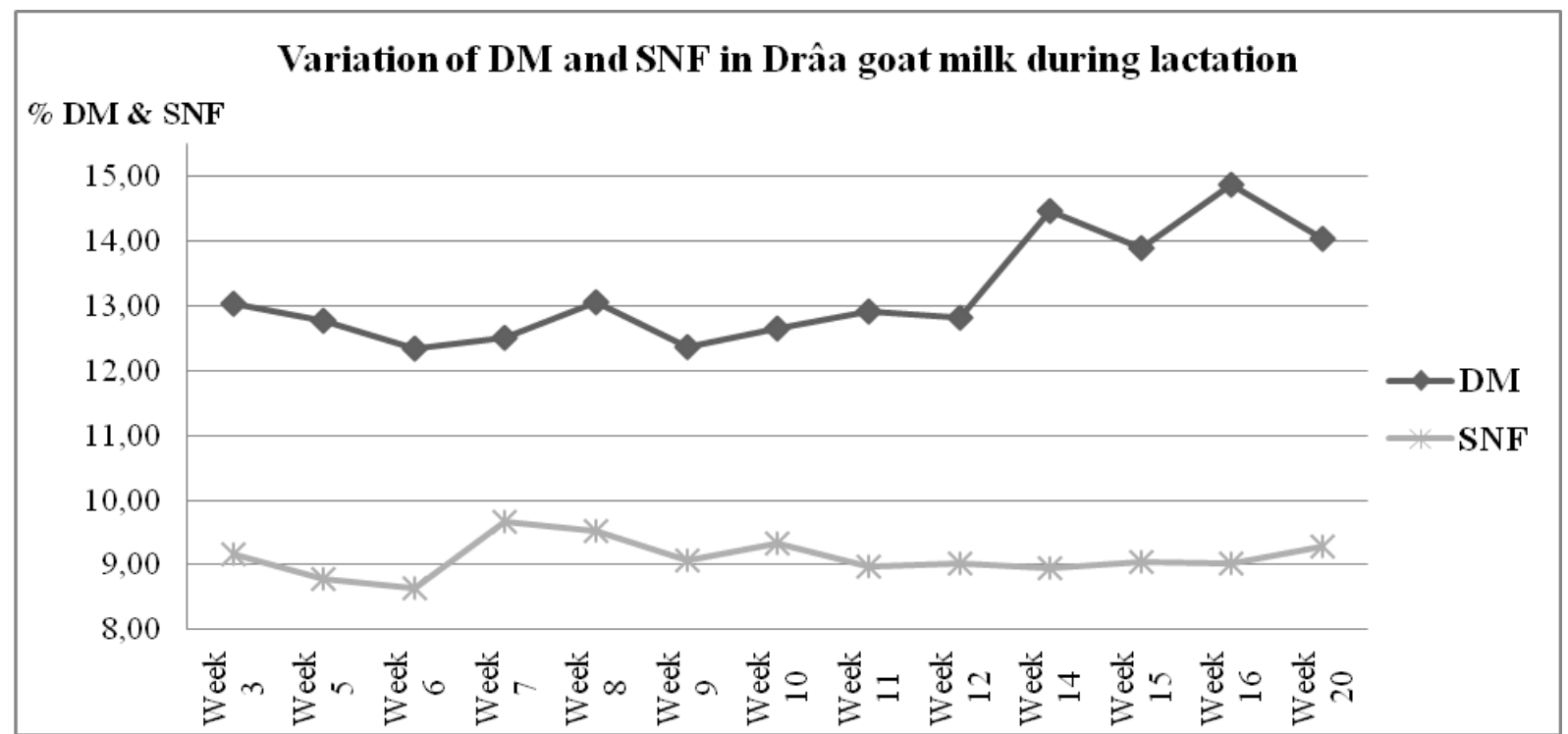

Figure 2: Variation of DM and SNF in Drâa goat milk during lactation

The change in SNF content is less pronounced than that of DM especially in the late lactation.

The influence of lactation stage on the physicochemical composition of Drâa goat milk

The means contents of physical and chemical components of milk at each stage of lactation (beginning, middle and end) are given in Table 2.

During lactation, a significant increase $(\mathrm{p}<0.001)$ in dry matter, fat and total nitrogenous matter was identified. The opposite trend was observed for density. However, the acidity of Drâa goat milk remains stable without significant change.

\section{DISCUSSION}

\section{Characterization of the physicochemical composition of Drâa goat milk}

The mean values for the various physicochemical parameters of Drâa goat milk are comparable to those reported for North Moroccan goat milk except for acidity which is much lower $\left(18^{\circ} \mathrm{D}\right.$ Vs $27^{\circ} \mathrm{D}$ for the North) [5].In general, values found are largely situated in the upper level of the range reported in other studies by several Moroccan and foreign authors [6] [7] and [8]. Thus, the percentage of $4.16 \%$ shown for fat content is well above the 4.15 found by several researchers. The TNM content has a 


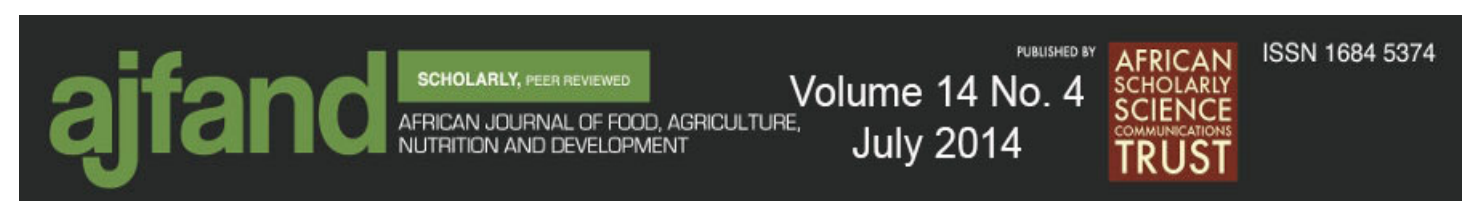

direct influence on cheese yield. Its mean value was about 3.6\%, indicating a good capacity for cheese making of this milk.

The protein content was higher compared to milk of Saanen goat (2.7\%) [9] and the Alpine race (2.7\%) [10], and similar to that of Murciana Grandiana race (3.5 to 3.6\%) [11].

\section{The evolution of fat and TNM during lactation}

The rate of change presented in Figure 1 for the fat and the TNM is entirely consistent with the results reported in the literature [6]. In fact and except the slight increase of fat from the 12th week of lactation around 5\%, there is a quasi-stabilization of both parameters around $3.5 \%$. Milk analyzed in this study is richer with fat and TNM in late lactation compared to the beginning, especially for fat:

- Fat: $4.76 \%$ at the end of lactation against $3.86 \%$ at the beginning, with an average spread of $0.90 \%$;

- TNM: $4.18 \%$ at the end of lactation against 3.42\% at the beginning, with an average spread of $0.76 \%$.

The increase in levels of these two components during lactation is related specifically to the quantity and the quality of feed and also to the decrease in quantity of produced milk; it is well-known that fat curve has a variation inversely proportional to milk production [6].

\section{Study of the evolution of DM \& Solids Non Fat (SNF) during lactation}

Solids Non Fat content varies slightly during lactation stage, which justifies the obtained results for the small variation in TNM (Figure 1); however, the DM content fluctuates very considerably from the 12th week. The amount of fat contained in milk plays, therefore, an important role in the variation of dry matter especially when we consider large quantities; in this context and if we project the curve of DM (Figure 2) on that of fat in Figure 1, it is very clear that they follow the same trend, and especially towards the end of lactation, when fat content reached their highest levels.

\section{The influence of lactation stage on the physicochemical composition of Drâa goat} milk

a. Chemical parameters

\section{- Ashes}

Statistically, no significant effect of lactation stage on the mineral content of milk was observed ( $p>0.05$ ). Moreover, it is appropriate to note that the content of ash was slightly higher at the end of lactation with an average of $0.743 \%$ compared to the beginning $(0.732 \%)$. Results of this study are consistent with those obtained by [5]. The opposite was found by [12] who argued that the salt content of the milk of local goats in India increased significantly throughout the lactation stage. 


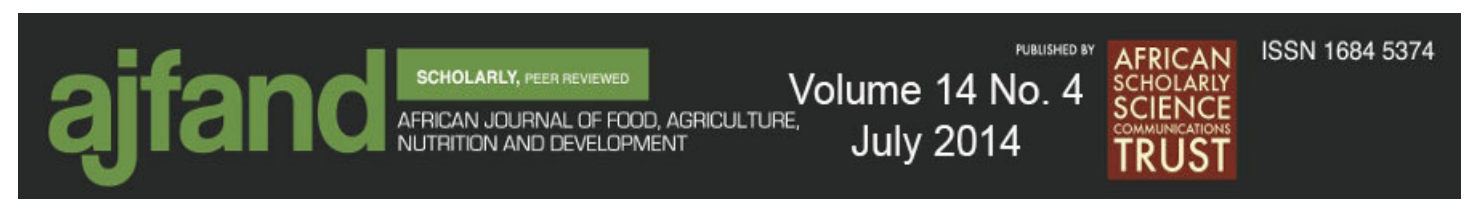

- Dry matter

The dry matter content increases in a very highly significant manner during the stages of lactation. Its mean value increased from $13.3 \%$ to $16.6 \%$ at the 16 weeks.

These results are consistent with those reported by others who observed an increase in dry matter with the advancement of lactation [5, 12, 13]. This trend can be attributed to the decrease in milk production during lactation [9].

\section{- Fat and total nitrogenous matter}

Analysis of variance revealed a very highly significant increase in fat content ( $\mathrm{p}<$ $0.001)$ and a highly significant increase for TNM content $(\mathrm{p}<0.005)$.

This general trend synchronizes with observations given by [14] and [15]. In light of these results, it is clear that every breeder-cheese manufacturer should know that with the same volume of milk, he gets more quantity of cheese in late lactation than during the months of high milk production (usually the middle of lactation).

b. Physical parameters

- Density

During the lactation period, milk density significantly decreases $(\mathrm{p}<0.001)$ from $1.0327 \mathrm{~kg} / \mathrm{l}$ to $1.0293 \mathrm{~kg} / \mathrm{l}$ at the end of lactation. This result seems quite logical, knowing that this parameter varies in an inversely proportional manner to the fat content, because fat content increases during lactation.

\section{- Acidity}

The results showed that the evolution of lactic acid content in Drâa goat milk according to the stage of lactation remains not significant $(\mathrm{p}>0.05)$; the acidity average was about $16.7^{\circ} \mathrm{D}, 17.9^{\circ} \mathrm{D}$ and $17.2^{\circ} \mathrm{D}$ for the beginning, the middle and the end of the lactation.

These results agree with those found by others for goats in Northern Morocco and for an unspecified French goat $[5,16]$. These results indicate that milking in this study was conducted under better conditions, because the high variability of titratable acidity throughout the lactation stage is an indication of poor hygienic conditions during milking [15].

- $p H$

The statistical treatment of $\mathrm{pH}$ data shows that the $\mathrm{pH}$ of milk does not vary between the middle and late lactation. However, it decreases in a very highly significant manner between the early and late lactation $(p<0.001)$. This result is consistent with what has been cited in the bibliography. Nevertheless, these observations are in partial disagreement with other studies [17].

\section{CONCLUSION}

Through this study, characterization of Drâa goat milk, as local product of oases region of Southern Morocco, was established. It was observed that milk is rich in fat 


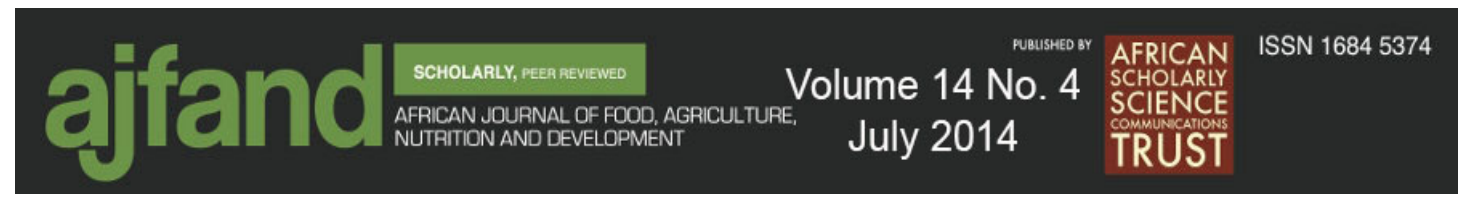

(4.16\%) and in Total Nitrogen Matters (3.60\%) reflecting a better ability for cheese making. In parallel, it was concluded that the stage of lactation had no effect on the mineral content (ash) and lactic acid. However, the chemical composition of Drâa goat milk is directly influenced by the stage of lactation; that is, levels of dry matters, fat and TNM increase significantly during lactation.

In practice, it is clear from this study that with the same amount of milk, we get more quantities of cheese at the end of lactation compared to the beginning, seen the quantity of TNM at this period.

In addition, the end of lactation seems like as an excellent period to ensure the best yields in the manufacture of dairy fatty product (butter, cream).

Finally, in order to overcome the fluctuations in these two components (fat \& TNM) that directly affect the technological quality of dairy products, it is recommended to go through a standardization before any processing, especially at industrial scale.

\section{Acknowledgement}

A sincere appreciation is expressed to Mrs. M. BAHA for her laboratory assistance and to Miss. M. LLORENTE \& Mr. A. NOUTFIA for assistance in the elaboration of this paper. 


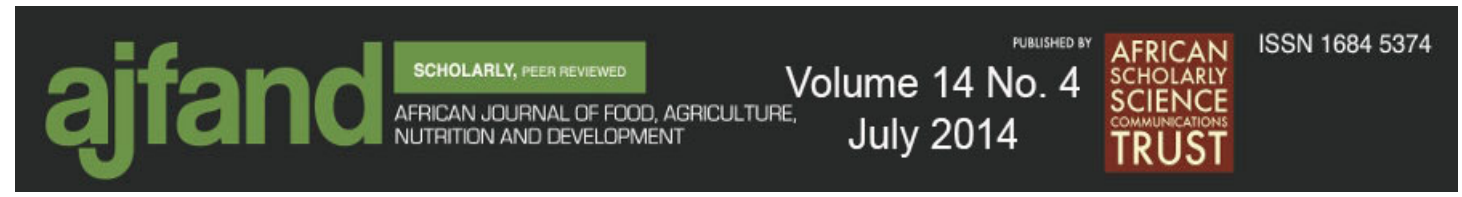

Table 1: Physicochemical composition of Drâa goat milk

\begin{tabular}{ccccc}
\hline & Average & Maximum & Minimum & S.D \\
\hline pH & 6.64 & 7.05 & 6.09 & 0.15 \\
Density (kg/l) & 1.0313 & 1.0395 & 1.0222 & 0.003 \\
Acidity ( $\left.{ }^{\circ} \mathbf{D}\right)$ & 17.75 & 29.00 & 13.50 & 2.27 \\
Dry Matters (\%) & 13.32 & 17,54 & 9.95 & 1.63 \\
Ashes (\%) & 0.728 & 0.900 & 0.539 & 0.078 \\
Fat (\%) & 4.16 & 7.50 & 1.20 & 1.57 \\
TNM (\%) & 3.60 & 5.27 & 2.82 & 0.41 \\
Lactose* (\%) $^{\text {(\%) }}$ & 4.83 & --- & --- & --- \\
\hline
\end{tabular}

*: Value deduced by subtraction.

Table 2: Physicochemical characterization of milk during the stage of lactation; $\mathrm{n}=128$

\begin{tabular}{lcccc}
\hline & $\begin{array}{c}\text { Early } \\
\text { lactation }\end{array}$ & $\begin{array}{c}\text { Middle of } \\
\text { lactation }\end{array}$ & $\begin{array}{c}\text { End of } \\
\text { lactation }\end{array}$ & p \\
\hline pH & $6.82^{\mathbf{a}}$ & $6.62^{\mathbf{b}}$ & $6.70^{\mathbf{c}}$ & $* * *$ \\
Acidity $\left({ }^{\circ}\right.$ Dornic) & 16.73 & 17.90 & 17.22 & n.s \\
Density (kg/l) & $1.0327^{\mathbf{a}}$ & $1.0316^{\mathbf{b}}$ & $1.0293^{\mathbf{c}}$ & $* * *$ \\
Dry Matters (\%) & $13.35^{\mathbf{a}}$ & $13.44^{\mathbf{b}}$ & $16.16^{\mathbf{c}}$ & $* * *$ \\
Fat Content (\%) & $3.83^{\mathbf{a}}$ & $3.88^{\mathbf{b}}$ & $5.39^{\mathbf{c}}$ & $* * *$ \\
TNM (\%) & $3.54^{\mathbf{a}}$ & $3.47^{\mathbf{a}}$ & $4.24^{\mathbf{b}}$ & $* * *$ \\
Ashes (\%) & $0.738^{\mathbf{a}}$ & $0.734^{\mathbf{a}}$ & $0.797^{\mathbf{b}}$ & $* *$ \\
\hline \multicolumn{4}{c}{ Averages followed by a different letter are statistically different. The } \\
\multicolumn{2}{c}{ difference may be non-significant (p>0.05), * significant $(\mathrm{p}<0.05), * *$ highly } \\
\multicolumn{4}{c}{ significant (p<0.005) and ***very highly significant (p<0.001). }
\end{tabular}




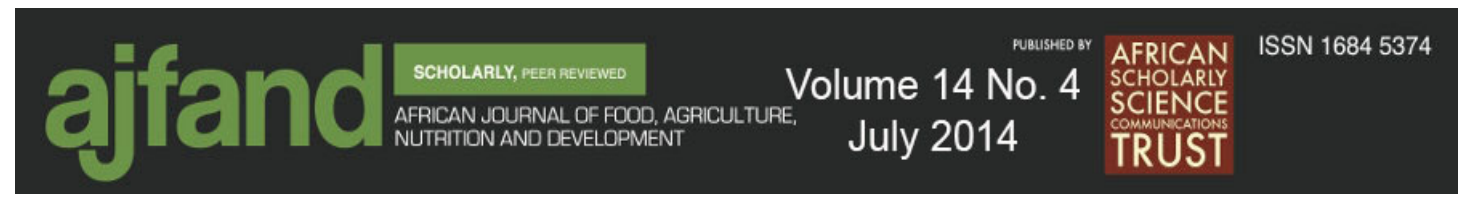

\section{REFERENCES}

1. ADA. Agence de Développement Agricole. www.ada.gov.ma, 2009.

2. ORMVAO Office Régional de la mise en Valeur Agricole d'Ouarzazate. Revue l'Eleveur, 2008 ; 16 : 17 - 18.

3. Hilali $\mathbf{H}$ and $\mathbf{Y}$ Mouslih La chèvre Drâa: Potentiel de production et caractéristiques d'adaptation aux contraintes de l'environnement aride. Revue Terre et vie. $2003 ; \mathbf{6 6}: 1-2$.

4. AFNOR. Association française de Normalisation. Lait et produits laitiers : analyses physicochimiques. In : AFNOR (Ed.). Contrôle de la qualité des produits alimentaires. Paris La défense. 1993 : 220 - 251.

5. Zantar S, Chentouf $M$, Ibnelbachyr $M$, Chikhi $A$ and $L$ Iniguez Improvement of the goat keeper's income through the valorization of milk in cheese production in North and South of Morocco. In: El gharous M, Dahan R and El Mourid M (Ed.). Annual Report 2007-2008 (MCGP). Rabat. 2009: 68 -88 .

6. Le Jaouen $\mathbf{J}$ C Composition chimique et structure physicochimique du lait. In: Institut d'élevage (Ed.). La fabrication du fromage de chèvre fermier. Paris. 2004: $18-25$.

7. El Alamy $\mathbf{H}$ A, Senaity A and A M Kholif Manufacture of white soft cheese from goat's milk supplemented with skim milk powder. J. Agric. Sci. 1992; 17: 3875-3880.

8. Chilliard Y, Ferlay A, Rouel $\mathbf{J}$ and $\mathbf{G}$ Lamberet A review of nutritional and physiological factors affecting goat milk lipid synthesis and lipolysis. J. Dairy Sci. 2003; 86: 1751-1770.

9. Bouloc $\mathbf{N}$ Courbes de lactation des chèvres : quelques éléments sur leur forme. Revue de La chèvre. 1992 ; 193 :15 - 17.

10. Zeng S S, Escobar EN and T B Popham Daily variations in somatic cell count, composition, and production of Alpine goat milk. Small Rum. Res. 1997; 26: 253 - 260.

11. Analla M, Jimenez-Gamero I, Munoz-Serrano A, Seradilla $J$ M and A Falagan Estimation of genetic parameters for milk yield and fat and protein contents of milk from Murciana-Granadina goats. J. Dairy Sci. 1996; 79: 1895-1898. 
12. Bhosale S S, Kahate P A, Kamble K, Thakare V M and S G Gubbawar Effect of Lactation on Physico-Chemical Properties of Local Goat Milk. Vet. World J. 2009; 2: 17 - 19.

13. Güney $\mathbf{O}$, Torun $\mathbf{O}$, Özuyanık $\mathbf{O}$ and $\mathbf{N}$ Darcan Milk production, reproductive and growth performances of Damascus goats under northern Cyprus conditions. J. Small Rum. Res. 2006; 65: 176 - 179.

14. Parsad H, Tewari $\mathbf{H}$ A and O P S Sengar Milk yield and composition of the Beetal breed and their crosses with Jamunapari, Barbari and Black Bengal breeds of goat. J. Small Rum. Res. 2005; 58:195 - 199.

15. Pavic V, Antunac N, Mioc B, Ivanovic A and $\mathbf{J} \mathbf{L}$ Havranec Influence of stage of lactation on the chemical composition and physical properties of sheep milk. Czech J. Anim. Sci. 2002; 47: 80 - 84.

16. Anonyme Aptitude acidifiante et caractérisation biochimique et microbiologique des laits et des sérums dans la fabrication du Sainte Maure de Touraine. Bulletin d'information et d'échange de l'encadrement technique fromager fermier $2001 ; 7: 2-6$.

17. Tsioulpas A, Lewis $\mathbf{M} \mathbf{J}$ and A S Grandison A study of the $\mathrm{pH}$ of individual milk samples. Int. J. Dairy technol. 2007; 60: 96 - 97. 